\title{
Microbiological Characteristics of Raw Cow Milk in Beni Mellal Area (Morocco)
}

\author{
Nadia Ferdous \\ Sultan Moulay Slimane University, F.S.T \\ Biological Engineering Laboratory \\ Beni Mellal, Morocco
}

Mohamed Merzouki

Sultan Moulay Slimane University, F.S.T

Biological Engineering Laboratory

Beni Mellal, Morocco

\section{Fatiha Chigr}

Sultan Moulay Slimane University, F.S.T

Biological Engineering Laboratory

Beni Mellal, Morocco

\author{
Rachid Hnini \\ Sultan Moulay Slimane University, F.S.T \\ Biological Engineering Laboratory \\ Beni Mellal, Morocco
}

Lhoucine Bahi

Sultan Moulay Slimane University, F.S.T

Biological Engineering Laboratory

Beni Mellal, Morocco

\author{
Mohamed Najimi \\ Sultan Moulay Slimane University, F.S.T \\ Biological Engineering Laboratory \\ Beni Mellal, Morocco
}

\begin{abstract}
Although a great effort has been made in Morocco concerning the produced quantity of raw cow milk, its quality does not meet acceptable quality standards. Theobjective of this study was to evaluate the global milk quality in Moroccan dairy herds (hygienic and pathogenic parameters) and the perspectives on dairy development.

For this, we evaluated the variations in the overall quality of raw milk: bacteriological and hygienic characterizations. Thus, samples of raw cow's milk produced in 10-12 farms were selected from different areas in Beni Mellal region. The investigation has concerned different cattle farms with different breeding procedures. Thus, microbiological characterization was evaluated in the samples analyzed for their standard plat count, total coliform and fecal coliform, yeast loads (L), molds (M) and some of pathogenic bacteria (staphylococcus, salmonella, listeria and clostridium). In general, the samples analyzed show a moderate to critical contamination of raw milk during different seasons in all microbial species analyzed, notably for fecal and total coliforms and total mesophilic aerobic flora (TMAF). As the microbiological quality of milk is critical to the health, organoleptic and technological qualities of milk, we assayed pathogenic bacteria and found a positivity only for staphylococcus aureus which exceeds the accepted limit. The most contaminated farms were those located essentially in the irrigated zones. The less contaminated ones belong to modern's farms. It seems that transportation, milking and pre-storage conditions as well as climate constitute the main basic relevant factors for heavy bacterial contamination Taken together these variations reflect essentially differences in practical breeding. When the period effect is investigated, differences between hot periods and cold-warm periods are present for the parameters mentioned above. These results indicate the non-respect of good hygiene practices as well as breeding practices.
\end{abstract}

Key words: raw cow milk, global milk quality, microbiological characterization, Beni Mellal, Morocco.

\section{INTRODUCTION}

In Morocco, the dairy industry is undergoing many problems related to the quality standards which are very hard to meet [1-4] and [5, 6]. This is due particularly to two major factors. The first one is the heterogeneity of raw milk's compositions, influenced by many factors such as the geographical area, breeding, climate conditions and nutritional factors [6] and [7]. Secondly, the difficulty to respect hygienic procedures leading to an important microbial load affecting de facto the hygienic quality and representing in this a serious concern for human health [8]. In final, the conjugated factors affect the global quality of the raw milk destined to industrial processing (pasteurized or sterilized milk and other dairy products). The dairy industries were in the obligation to modify for example the pasteurization or the sterilization scale by increasing treatment time and by consequence a significant economic loss. Reducing the production costs is becoming more important in the dairy industry. This stresses the dairy industries on urgency to face to this problem by choosing the adequate collecting farms and cooperatives. This passes via the analysis of the physicchemical properties as well as the microbiological load of the collected dairy raw milk to retain only those presenting standard quality or at least are close to these standards [4]. Although, the Moroccan government made great efforts to organize milk collection centers (chain approach), some of them do not respect all the rules instituted by the official services. The approach we propose in this investigation will help both producers and industrials. Concerning producers, this will force them to improve their way in breeding and hygienic practices and to be eligible to buy their dairy production to the 
industrials. Concerning these latters they will have a precise map concerning the localization of the good and the worst centers. Our previous studies have shown that raw cow milk produced in Beni-Mellal area display high variability among geographical subdivisions. This study will extend these findings by assessing the microbiological characteristics in all representative geographical subdivisions providing the most dairy industries of the region of Beni Mellal. The main objective of the research was twofold: firstly, to study the impact of bacterial load $(\mathrm{CFU} / \mathrm{mL})$ in the quality of fresh milk in small cattle farms based on existing standards for fresh quality milk; secondly, to draw valuable recommendations for the overall dairy industry and food safety standards in Beni Mellal area.

\section{MATERIEL AND METHODS}

\subsection{Study area and data sources}

\subsubsection{Studied area and study period}

This study was performed in the irrigated perimeter of Benimellal situated in Tadla Plain in central of Morocco from March 2013 to January 2014. The climate of the Tadla region is known by arid to semi-arid with a dry season from April to October and it is also characterized by a rainy season from November to March. The annual cumulative rainfall changes from 149 to $397 \mathrm{~mm}$ between 2000 and 2013 while the seasonal variations of temperature are significant with a maximum in August of $46{ }^{\circ} \mathrm{C}$, a minimum in January of $-6{ }^{\circ} \mathrm{C}$ and an annual average of $20{ }^{\circ} \mathrm{C}$ [9]. The plain parts are well developed and the agriculture is generally based on irrigation methods and many farms have developed their activities inside them. In some parts the community is more agropastoralist and there is large milk production from cows and goats. The study populations were raw cow's milk from cooperatives of ten different zones. So, 10 dairy cooperatives in the Beni Mellal region were selected for this study. They were chosen by the variability type of feeding, geographical location and conditions hygienic procedures for the receipt of milk at the cooperative level. The sampling points were principally milking buckets at farm level or transport containers. Just after receiving the raw milk in the cooperative, we samples are taken in sterile vials. The samples are transported directly to the laboratory in a cooler. The maximum time between sampling and the analysis of the samples did not exceed 2 hours. The Samples was taken for four periods during the year, during summer, autumn, winter and spring.

\subsection{Microbiological analysis}

Dilutions of milk samples studied (in peptone water) varied from $10^{-1}$ to $10^{-7}$. The isolation and enumeration of mesophilic aerobic flora, total coliforms, fecal coliforms, anaerobic sulphite-reducing bacteria, $\underline{\text { Staphyloccoccusaureus, }}$ yeasts and molds, were carried out according international standards [10].

Bacteria enumeration: for mesophilic aerobic flora, the non-selective culture medium Plate Count Agar (PCA) was used and the incubation conditions were $72 \mathrm{~h}$ at $30^{\circ} \mathrm{C}$. Then, the count of colonies was performed 24 and $48 \mathrm{~h}$. Concerning the enumeration of coliforms, we used the Desoxycholate Lactose Agar (DL, Oxoid, England), a selective medium for the detection of enterobacteriacea. The incubation was operated during $48 \mathrm{~h}$ at $30^{\circ} \mathrm{C}$ to determine total coliforms or at $30^{\circ} \mathrm{C}$ for fecal coli forms. Only red colonies (lactose+) with a minimal diameter of $0.5 \mu \mathrm{m}$ were considered. The estimation of $\underline{\text { S.aureus, }}$, the incubation of diluted milk samples was made in Baird Parker media during $48 \mathrm{~h}$ at $37^{\circ} \mathrm{C}$. For the estimation of Salmonella, the Rappaport-Vassiliadis broth was used (24 $\mathrm{h}$ at $\left.42^{\circ} \mathrm{C}\right)$ and Hektoen medium $\left(24 \mathrm{~h}\right.$ at $\left.30^{\circ} \mathrm{C}\right)$. The confirmation of identification of suspect colonies was made by the aid of API20 E kit (Biomérieux, France). Finally for Listeria monocytogenes detection, we used broth Frazer $\left(24 \mathrm{~h}\right.$ at $\left.37^{\circ} \mathrm{C}\right)$. The confirmation of suspect colonies was performed by the use of chromogenic medium with the API Listeria.

Enumeration of fungal flora: for this aim, we incubated selected samples in Dextrose Agar Medium (PDA, Merck, England) during $72 \mathrm{~h}$ at $25^{\circ} \mathrm{C}$ for yeasts and 6-7 days for molds.

\section{RESULTS}

The results of the microbiological analysis of raw cow's milk produced in Beni Mellal area's zones are presented in Fig 1-8. Moreover, these figures show the seasonal evolution of bacterial load in different raw milk samples. The average of the bacterial load exceeds $10^{5} \mathrm{CFU} \mathrm{ml}{ }^{-1}$. Mean enterobacteriacea in bulk-tank raw milk samples collected from the ten farms investigated varied roughly from $10^{3}$ to $8.4 \times 10^{4} \mathrm{CFU} \mathrm{ml}{ }^{-1}$. The microbial analysis showed variability in the distribution of higher and lower bacteria during seasons, while higher values are present in autumn (from $8 \times 10^{3}$ to $8.4 \times 10^{4} \mathrm{CFU} \mathrm{ml}^{-1}$ ); relatively low loads were present in summer and spring (from $10^{3}$ to $1.5 \times 10^{4} \mathrm{CFU} \mathrm{ml}{ }^{-1}$ and from $4 \times 10^{3}$ to $2.7 \times 10^{4} \mathrm{CFU}$ $\mathrm{ml}^{-1}$ ) (Fig.1).

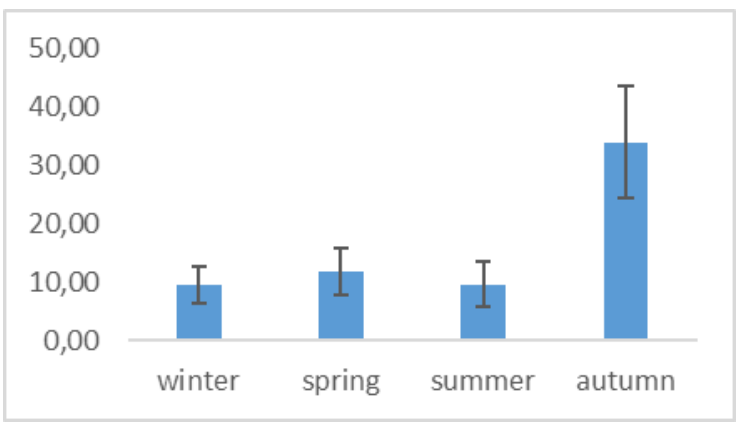

Figure 1: Bacterial levels are expressed as mean 


\section{\pm SEM of enterobacteriacea* $10^{3} \mathrm{CFU}^{*} \mathrm{ml}^{-1}$}

The highest mean seasonal total coliforms calculated on the basis of individual bulk-tank milk samples were observed in autumn too (from $7.3 \times 10^{4}$ to $6.49 \times 10^{5}$ CFU ml- Like enterobbacteriacea, a tendency in decreasing mean is observed from winter to summer displaying the lowest load (from $2 \times 10^{3}-2 \times 10^{4} \mathrm{CFU} \mathrm{ml}^{-}$

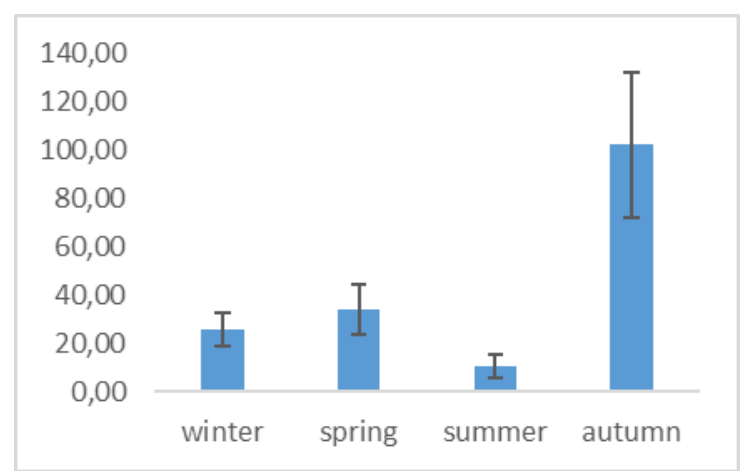

1) (Fig. 2).

Figure 2: Bacterial levels are expressed as mean \pm SEM of total coliforms $* 10^{3} \mathrm{CFU}^{*} \mathrm{ml}^{-1}$

When fecal coliforms are considered, the mean is higher during spring and autumn with a minimum and a maximum from $10^{4}$ to $5 \times 10^{5} \mathrm{CFU} \mathrm{ml}^{-1}$. The other 2 seasons display low average level (from $2 \times 10^{3}$ to $5.1 \mathrm{x}$ $10^{4} \mathrm{CFU} \mathrm{ml}^{-1}$ ). (Fig. 3).

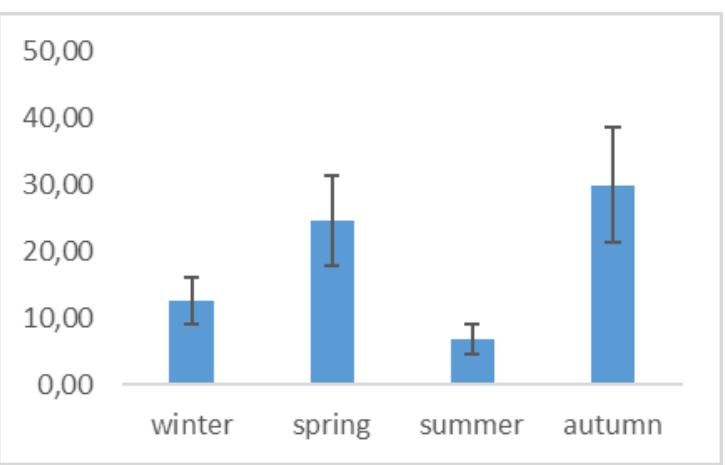

Figure 3: Bacterial level are expressed as mean \pm SEM of fecal coliforms $* 10^{3} \mathrm{CFU}^{*} \mathrm{ml}^{-1}$

Concerning mesophilic aerobic flora, higher mean values are present notably during all the year (from $10^{5}$ to $5 \mathrm{x}$ $10^{6} \mathrm{CFU} \mathrm{ml} \mathrm{m}^{-1}$ ) except for summer when the load is

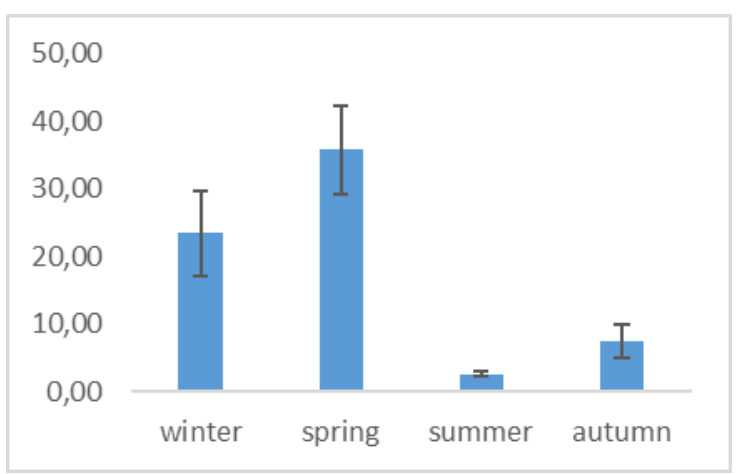

$\underline{\text { WwW.ijsea.com }}$ tenfold lower (from $10^{5}$ to $5 \times 10^{5} \mathrm{CFU} \mathrm{ml}^{-1}$ ) (Fig. 4).

Figure 4: Bacterial levels are expressed as mean \pm SEM of mesophilic aerobic flora*10 $\mathrm{CFU}^{*} \mathrm{ml}^{-1}$

Similar evolution tendency is observed for yeast and at lesser degree molds (Figs. 5 and 6)..

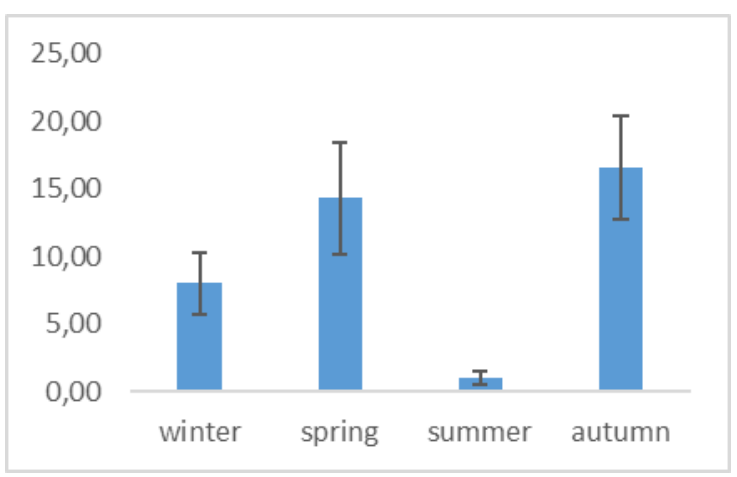

Figure 5: load levels are expressed as mean $\pm \mathrm{SEM}$ of yeast $* 10^{4} \mathrm{CFU}^{*} \mathrm{ml}^{-1}$

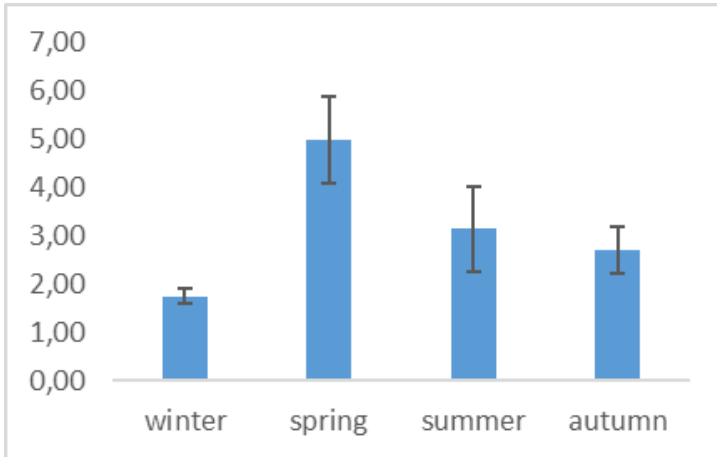

Figure 6: load levels are expressed as mean ${ }^{1}$ \pm SEM of molds $* 10^{4} \mathrm{CFU}^{*} \mathrm{ml}^{-1}$

Opposite to this pattern, Pseudomonas shows low levels during spring (Fig. 7) although the average mean is higher (from $10^{5}$ to $5 \times 10^{5} \mathrm{CFU} \mathrm{ml}^{-1}$ ).

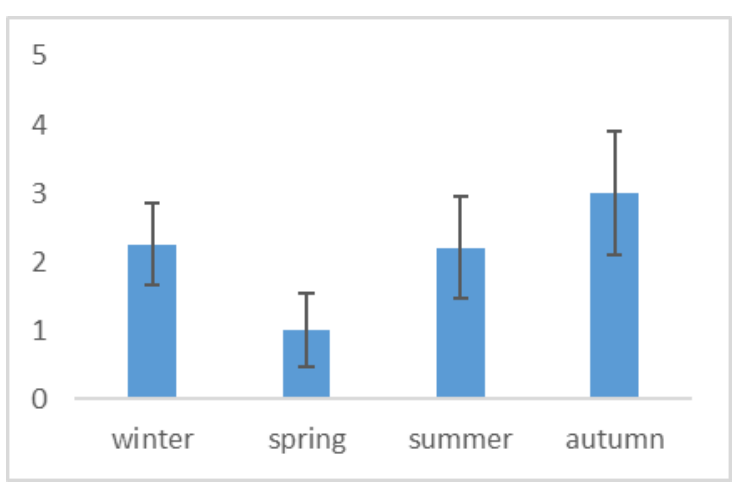

Figure 7: load levels are expressed as mean \pm SEM of Psodomonas CFU*ml-1 
For thermoresistant bacteria there is no clear season effect (Fig 8). The values are comprised from 10-80 CFU $\mathrm{ml}^{-1}$ as minimal values to $3.3 \times 10^{2}-4.6 \times 10^{2}$ ). We have not been able to detect listeria monocytogenes, clostridium as well as salmonella sp. Concerning, staphyloccocos aureus, highest values are detected during summer whereas they are low during winter (Fig. 9).

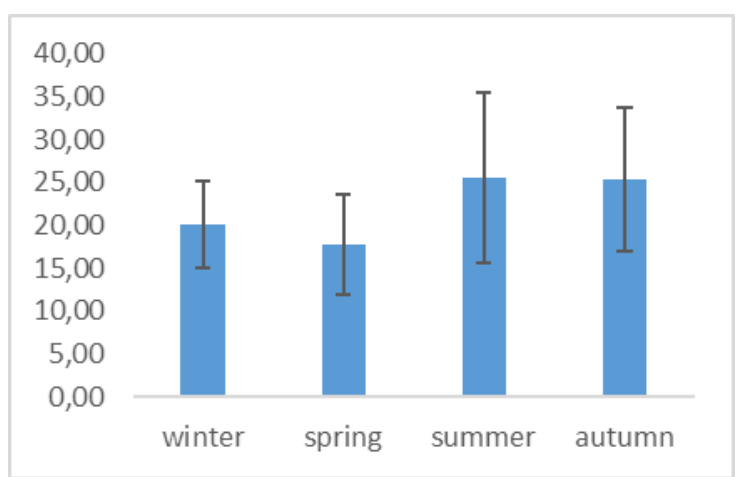

Figure 8: Bacterial levels are expressed as mean \pm SEMof thermoresistant bacteria $\mathrm{CFU} * \mathrm{ml}^{-1}$

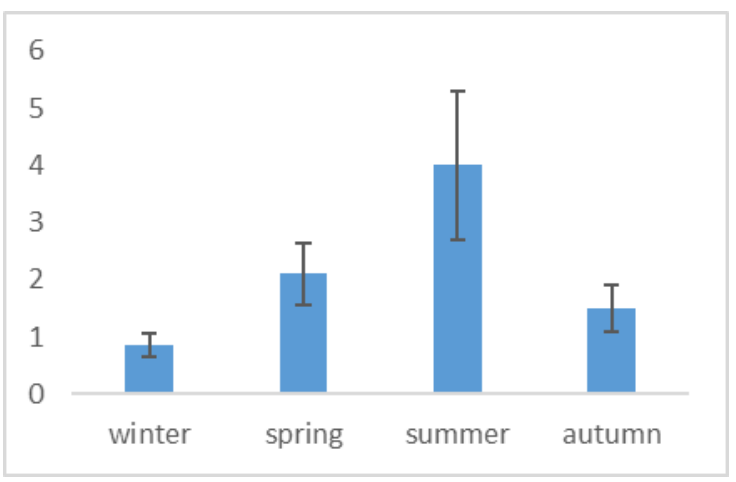

Figure 9: Bacterial levels are expressed as mean \pm SEM of Staphylococcus aureus $* 10^{3} \mathrm{CFU}^{*} \mathrm{ml}^{-1}$

\section{DISCUSSION}

In the present study, we investigated the microbiological characteristics of raw cow milk produced in the area of BeniMellal. This geographical region is renewed for its agro production, as well as the implementation of the majors in dairy industry. Indeed, the region was one of the first production areas dairy in Morocco [11]. In this context, the evaluation of the bacteriological quality of milk is necessary and essential to determine the points of failure during the production of the raw material, in order to protect the consumer, master the quality of the finished product.

The analysis of the microbiological data obtained for all the samples investigated revealed that the great majority of milk samples were contaminated but at different levels. Thus, in Morocco, the number of coliforms reported in raw milk is generally high [12]. The report of Ounine et al. [1] and Menane et al. [13] (in the Gharb region resulted in an enumeration in the order of $1.07 \mathrm{x}$ $10^{7} \mathrm{UCF} \mathrm{ml} \mathrm{m}^{-1}$ and $1.99 \times 10^{6} \mathrm{UCF} \mathrm{ml} \mathrm{m}^{-1}$ respectively for total and fecal coliforms. In the same area, samples of raw milk taken from the collection centers showed an average grade of Coliforms of $1.8 \times 10^{4} \mathrm{UCF} \mathrm{ml}^{-1}$.

The results of our study in the region of Beni Mellal, show that there are marked variations as regards the microbial charge. This heterogeneity is well illustrated when season is taken in consideration. By the case of summer, which shows the most Low of $2.4 \times 10^{3} \mathrm{UCF}$ $\mathrm{ml}^{-1}$ and $2.4 \times 10^{4} \mathrm{UCF} \mathrm{ml} l^{-1}$ respectively For FC and TC and the autumn which was the more loaded with a level of $5.1 \times 10^{4}$ and $6.4 \times 10^{4} \mathrm{UCF} / \mathrm{ml}$ respectively for FC and TC. A similar tendency was reported by Afif and al. [6] in the Tadla plain where Beni Mellal region is situated but our results show slight differences with relative decrease in microbiological load.

It seems that several efforts have been made to avoid biological contamination but the effort still to be more pronounced. The highest microbiological loads present in certain collecting points are certainly due to failure in respecting basic hygiene rules notably in pre-milking udder preparation and milk handlers, and also when storage equipment and transportation processes to the collect point by individual farms processes [14-8] and [615].

This was confirmed by our observations made for some collecting points. Based on observations made during the collection of samples, we therefore report that improper hygiene and poor farm management practices contributed to the presence of these isolated bacteria in the milk. In this study area, milk was obtained from animals by washing their hands and/or the utensils and containers used. In certain cases, untreated groundwater was used to wash the containers that were used for milking.

Improving the hygienic conditions of the milking environment and/or utensils may reduce the prevalence of enteropathogenic bacteria. This could be confirmed by the presence of thermoresistant bacteria even at low levels but this indicative of high original bacterial load.

When staphylococcus count in raw milk is considered, Beni Mellal region displayed low loads compared to other Moroccan regions notably in the Gharb region $(5 \mathrm{x}$ $\left.10^{5} \mathrm{UCF} / \mathrm{ml} ;[16]\right)$, and in the Rabat region $\left(25 \times 10^{5}\right.$ $\mathrm{UCF} / \mathrm{ml} ;[17])$.

The average of staphylococcus load is up to $10^{3} \mathrm{UCF} / \mathrm{ml}$ and is in equivalent tendency to that reported to Tadla region (encompassing Beni Mellal area) (up to $5 \times 10^{3}$ $\mathrm{UCF} / \mathrm{ml}$; [6]) and at lesser degree to that reported in Oujda city [4]. Staphylococcus species besides streptococcus species were the most commonly isolated bacteria in milk produced by animals with subclinical mastitis [18] and [19].

Our results which are slightly different from those of Afif et al. [6]in the same area, show firstly that an effort has been made in the sense of ameliorating the quality of raw cow milk and secondly that they are in favor of a relative respect of hygienic procedures in the cooperatives investigated and this could be in part explained by the this can be explained by the necessity of the producers to respect the conditions of the manufacturers. However, a supplementary and sustainable effort has to be made to ameliorate more the hygienic quality.

The quality of fresh milk in Beni Mellal area as depicted in the results presented in this study still remains quite low in certain cooperatives in comparison with existing standards and needs an immediate improvement by applying best practices advanced and appropriate intervention in infrastructure. However, compared to our previous results in the same area but at different 
collecting cooperative points, a tendency in decreasing concerning the

microbiological load is observed. This is due probably to the efforts made by industrials towards farmers to respect hygienic standards by financial encouragements or by economic sanctions.

Interestingly, the raw cow milk produced

In Beni Mellal area did not display an conta-mination with Lisreria monocytogenes nor with salmonella sp. This is in the line of our previous findings, not reporting on such

contamination in other geographical zones of milk collection [5,6]. Previous studies in other areas in Morocco have not reported any contamination in collected raw milk [2] and [13].

The only exception was the report of Hadrya et al.[15], but concerning not processed milk bought in specialized shops dedicated to raw products rather than raw milk produced in farms and destined to be processed industrially. Certainly, the temperature conservation procedures have not been respected.

Taken together, the results presented in this investigation show that raw cow milk produced in Beni Mellal area presents variability concerning the microbiological contamination and in several cooperatives, a consistent effort has to be made to face to factors causing it. Although this effort has to be implemented, we notice a positive evolution concerning the quality of fresh milk produced in many other cooperatives.

\section{CONCLUSION}

The overall quality of milk produced in Beni Mellal area did not meet hygienic standard quality and improvements have to ne made.

\section{REFERENCES}

[1] Ounine, K., Rhoutaisse, A. and El Halou, N.E. 2004. Caractérisation bactériologique du lait cru produit dans les étables de la région du Gharb. Al awamia, 109-110 : 187-204.

[2] Srairi, M.T., Hasni Alaoui, I., Hamama, A. et Faye, B. 2005. Relations entre pratiques d'élevage et qualité globale du lait de vache en étables suburbaines au Maroc. Revue Méd.Vét. 156 (3) : 155-162

[3] Taybi N,O, Arfaoui A, Fadli M, 2014, Evaluation of microbiological quality of raw milk in the region of Gharb, Morocco. Int J InnovSci Res., 9; 487-93

[4] Mchiouer, K, Bennani S, El-GendyN.Sh, Meziane M (2017) Evaluation of the hygienic quality of raw cow's milk in Oujda city Morocco.Biosciences Biotechnology Res Asia 14: 587-91.

[5] Afif, A., M. Faid and M.Najimi, 2007. Effects of breeding and hygienic practices on raw cow milk quality in Tadla area, Morocco. Livest. Res. Rural Dev., 19 (12).

[6] Afif , A., Faid, M., Najimi M (2008) Qualité microbiologique du lait cru produit dans la région de Tadla au Maroc. Reviews in Biology and Biotechnology. 7: 2-7
[7] Angulo, F,I, LeJeune J,T, Rajala-Schultz P,J, 2009, Unpasteurized milk: A continued public health threat. Clinic Infect Dis 48; 93-100

[8] Le Jeune J.T and Rajala-Schultz P.J (2009) Unpasteurized milk: A continued public health threat. Food safety 48: 93-100.

[9] Abderrazak El Harti, RachidLhissou, KaremChokmani , Jamal-eddineOuzemou, Mohamed Hassouna, El MostafaBachaoui , Abderrahmene El Ghmari. Spatiotemporal monitoring of soil salinization in irrigated Tadla Plain (Morocco) using satellite spectral indices. International Journal of Applied Earth Observation and Geoinformation 50 (2016) 64-73.

[10] ICMSF., 1986. Microorganisms in Foods 2. Sampling for Microbiological Analysis: Principles and Specific Applications. 2nd Edn., University Toronto Press, Canada.

[11] M.A.M.V.A. 2000. Ministère de l'agriculture et de la mise en valeur agricole. Direction de l'élevage.

[12] Kbibou, G., 1987. Etude bactériologique des produits laitiers traditionnels. Thèse de Doctorat Vétérinaire. Filière Vétérinaire. IAV Hassan II, Rabat, Maroc.

[13] Mennane Z., Ouhssine M., Khedid K., Elyachioui M. (2007) Hygienic quality of raw cow's milk feeding from domestic waste in two regions in Morocco. Int $\mathbf{J}$ AgriBiol 9:46-48.

[14] McKinnon CH., RowlandsGJ.,Bramley AJ. (1990), The effect of udder preparation before milking and contamination from the milking plant on bacterial numbers in bulk milk of eight dairy herds. J Dairy Res 57: 307-318.

[15] Stulova I, Adamberg S, Krisciunaite, Kampura M, Blank L, Laht T-M (2010) Microbiological quality of raw milk produced in Estonia. Letters in applied microbiology 51: 683-690.

[16] F Hadrya, AElouardi, D Benali, H Hami, A Soulaymani, S Senouci (2012) Bacterial Quality of Informally Marketed Raw Milk in Kenitra City, Morocco. Pakistan Journal of Nutrition, 11: 8 ; 760-767

[17] Hamama, A. 2002. Cours de formation des techniciens de l'Office Régional de Mise en Valeur Agricole du Haouz. Rabat.

[18] White D.G, Harmon RJ, Matos JE, Langlois BE, (1989) Identification and isolation of coagulase-negative Staphylococcus species from bovine body sites and streak canals of multiparous heifers. J Dairy Sci. 22: 1886-92. 
International Journal of Science and Engineering Applications

Volume 6 Issue 10, 2017, ISSN-2319-7560 (Online)

[19] Wilson DI, Gonzales RN, Das H.H. (1997) Bovine mastitis pathogens in New York and Pennsylvania: prevalence and effects on somatic cell count and milk production. J Dairy Sci. 80: 2592-8. 